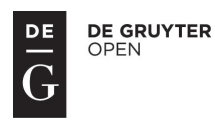

\title{
Assessment of National Program of Learning Regions IN Slovakia - DeSign AND TeSTING
}

\author{
Stanislav Kološta ${ }^{1}$, Lenka Sabelová ${ }^{2}$, Pavol Král ${ }^{3}$
}

\begin{abstract}
In May 2007, the Ministry of Education, Science, Research and Sport of the Slovak Republic approved the National Program for Learning Regions. It states that the long-term strategic objective for the development of Slovak regions is the gradual reduction of disparities in living standards in regions and to improve regional economic performance. One of the tools for achieving this goal is considered the learning region concept. The main aim of this article is to streamline the presentation and monitoring of the partial progress made in achieving the objectives of the National Program for Learning Regions in the Slovak Republic to policy-makers and to make this relatively complex issue accessible to a wider audience through one aggregated index and two partial indices; the PCA method was used. The results showed relatively large differences between regions. The highest value of the aggregated LR index was reached by the Trnava region, followed by the Bratislava region; these two regions seems to be in accordance with reaching the objectives of the National Program for Learning Regions. The lowest values were found in the Banská Bystrica, Prešov and Košice regions. Moreover, we found a positive correlation between aggregated and economical-innovative indices with average GDP during the years 2008-2014 at the NUTS 3 level.
\end{abstract}

\section{Keywords}

Learning Region, Principal Component Analysis, Index, Assessment, Regional Development, Indicator

\footnotetext{
${ }^{1}$ Faculty of Economics, Matej Bel University, Tajovského 10, 975 90, Banská Bystrica, Slovak Republic. E-mail: stanislav.kolosta@umb.sk.

${ }^{2}$ Faculty of Economics, Matej Bel University, Tajovského 10, 975 90, Banská Bystrica, Slovak Republic. E-mail: lenkasabelova@centrum.sk.

${ }^{3}$ Faculty of Economics, Matej Bel University, Tajovského 10, 975 90, Banská Bystrica, Slovak Republic. E-mail: pavol.kral@umb.sk.
} 


\section{Introduction}

Regions are considered spatial subdivisions of states and are characterized by a significant degree of spatial diversity. There is a widespread consensus in academic and policy debates that knowledge and innovation are eminently important for securing competitiveness, dynamic growth and the prosperity of regional economies (Asheim, Grillitsch, Trippl, 2015). Regional development can be perceived as a holistic process through the environmental, economic, social and cultural resources of the region that support continuous progress in ways that reflect the comparative advantages of individual geographic areas. An important feature of regional development is its sustainability. Regions also become the focal point of the economic, political, social and technical organization (Florida, 1995). Regional development is therefore a multidimensional term with enormous socio-economic variability, which is determined by the diversity of various factors widely reflected in the concepts and theories of regional development. Such an approach is also the learning region concept. In many countries, a general shift of innovation and labour market policies can be observed from the national to regional levels of decision-making, partly supported by supra-national organizations such as the EU and the World Bank (OECD, 2001). The learning region concept was updated in the EU through a European Commission grant under the Grundtvig (adult education) strand of the Lifelong Learning Program 2007-2013 within the R3L + project. This EU program stated that it is difficult to design effective strategies without the evaluation and quality assurance of various regional factors (Preisinger-Kleine, 2013). In May 2007, the Ministry of Education, Science, Research and Sport of the Slovak Republic approved the National Program for Learning Regions. It states that the longterm strategic objective for the development of Slovak regions is the gradual reduction of disparities in living standards in regions and one of the tools for achieving this goal was considered the learning region concept. In particular, the objectives of the program are: support regional science and research, partnership, innovation, education and life-long learning, employment and new job creation, sustainability in pursuing the goal of higher competitiveness and sustainable economic performance. What is lacking in this national program is the assessment of all its activities, which should be, at the end, reflected in the improvement of social-economic regional performance, i.e. the main objective of the program as well as Slovak regional policy. This could be in the form of a single aggregated indicator which evaluates the current status, progress or perspectives of Slovak regions towards the main objective of the national program using the available data and, if necessary, to determine which new regional data sets should be collected in future. This was the main motivation for constructing such indices.

The main aim of this article was to design and test an aggregated indicator called the aggregated LR index using the principal component analyses (PCA) as an indicator of overall progress and change in chosen regional indicators, which resulted in an assessment tool for policy-makers involved within the National Program for Learning Regions. The aggregated index is composed of economic-innovative and social-environmental partial indices. The regional characteristics used as input have a fairly wide range with respect to the National Program for Learning Regions. For this reason, such an index can be used as one of the 
instruments for monitoring and evaluating Slovak regional policy objectives. Our intention was to propose a comprehensive index usable for monitoring the state and progress based on input indicators in Slovak NUTS 3 regions which we consider particularly appropriate from the perspective of the Slovak National Program for Learning Regions. In Slovakia, practical regional policy is realized at NUTS 3 level, therefore all eight NUTS 3 regions were implemented within our study. We are aware of the limits in structure and reporting of data at Slovak NUTS 3 level, but the composition of the constructed index includes areas such as science and research, education, population migration as well as economic, social and environmental indicators directly related to the objectives of the Slovak National Program for Learning Regions. This study is the first to assess Slovak regions in terms of the learning region concept as well as the Slovak National Program for learning regions ${ }^{4}$.

\section{Theoretical background}

The learning region concept is usually based on the practice of successfully enforcing regions in the global economic environment - such as Silicon Valley, Baden-Württemberg, or Third Italy. Within the framework of institutional theories of regional development, the learning region concept was presented and developed in many studies (for example: Florida, 1995; Lundvall, 1992; Morgan, 1997; Gustavsen et al., 2007; Boekema et al., 2001; Hassink, Klaerding, 2012; Hudson, 1999; Saxena, 2005; Newlands, 2003; Rutten, Boekema 2007; Strambach, 1998; Ronde, Hussler, 2003; Newlands, 2003; Kološta, 2016). A common thread of these studies can be found in increasing the importance of learning processes, innovativeness and rising competitiveness within regional economies, where regional innovation systems ${ }^{5}$ respecting regional specifics (Storper, 1997) can be considered the basic framework of learning regions. On the one hand, a learning region does not have any strict definition and is considered a fuzzy concept (Boekema et al. 2001). On the other hand, it can be defined as a regional innovation strategy in which a broad set of innovation-related regional actors (politicians, policy-makers, chambers of commerce, trade unions, higher education institutes, public research establishments and companies) are strongly, but flexibly connected with each other, and who stick to a certain set of "policy principles" (Hassink, Klaerding, 2012; OECD, 2001).

Criticism of the concept of learning regions lies in the asymmetry of knowledge Akerlof defined in the 1970s. The weaknesses of this concept are in its ambiguous, normative character, and overlap with other similar theoretical directions as well as in its strong local focus and dependence on quality of human resources not paying much attention to industry differences and the position of firms in global production networks. Approaches such as localized learning (Lorenzen, 1998, 2001, 2007; Malmberg, Maskell, 2006) and spaces of learning (Faulconbridge 2006; 2007) did not prove to be an appropriate alternative for the learning region concept (Hassink, Klaerding, 2012). Learning processes and diffusion of innovation and knowledge do not end at regional borders. Rather, learning regions are

\footnotetext{
${ }^{4}$ Šipikal and Parízková (2009) tried to apply the learning region concept in one Slovak region, i.e. the Bratislava region.

${ }^{5}$ For more details on regional innovation systems (RIS), see Asheim, Grillitsch, Trippl (2015).
} 
beginning to be considered in a way that focuses on the process of learning, using and spreading knowledge on a spatial basis, i.e. the learning region is replaced by the term learning space. However, the learning region concept is unlikely to disappear because of the greater assimilation, processing, dispersion and creation of new knowledge by one region compared to the others - for example, if the region is in a phase of an adoptive or imitative innovation pattern, support which is centered on the formation of a territorial precondition for knowledge creation is not effective (Šipikal, 2013). Therefore, a learning region strategy will not be successful if it ignores the impact of national and even international innovation systems on inter-firm cooperation and innovative behavior. Different socio-economic potential of regions need specific innovation systems (Storper, 1997) respecting regional specifics.

Spaces of learning (Hassink, Klaerding, 2012) is unlikely to be considered a new theoretical concept because it basically combines learning processes, diverse types of relationships, cultural and social environments at different spatial and management levels into an integral whole. An economy built on the creation, exchange and use of knowledge in an environment where globalization is increasingly prominent is naturally required by such penetration (see Bathelt et al., 2004; Schamp, 2009). On the other hand, we need to realize that refusing the approaches presented so far and automatically adopting an "integrated" regional approach would not have to be successful in practice - for example, globalization influences the development of the regions, but they are at different stages of development and some links that are important in a globalized environment are in many cases absent (for example, regions outside main economic trajectories). Also, the cultural environments in which learning processes take place, as well as the creation and diffusion of innovations and knowledge vary. For this reason, attention is also drawn to the study of the cultural and social environment (or values) and the economy of enterprises/regions/countries to other entities due to the increasing openness of economies and the increasing linkages of business relationships. The objectification of these relationships seeks a relational economic geography that provides a more balanced view in which identical structural preconditions do not necessarily have the same effect at a different time and place, but may vary according to specific conditions (Bathelt, Gluckler, 2003). It has a strong focus on the strength of relationships, respectively their geometry (Yeung, 2005; Boggs, Rantisi, 2003). Rutten and Boekema (2007) have given a similar contribution at regional level within the development of the learning region concept. Despite criticism, the learning region concept has the potential to become a theoretical basis for modern regional innovation policies. We can summarize that sustainable improvement of life conditions and economic performance can be considered main objectives in regional policy using the learning region concept; the position of local firms within global production networks should not be omitted.

Critics and supporters of the learning region concept agree precisely on the importance of learning processes at local, regional and supra-regional levels and consistently argue that these processes are worth detailed study in different variations due to their unquestionable importance for the business sector as well as for the population, the environment, and the management of the territory. Ideas of this concept can also be seen in the smart specialization of regional growth within the EU cohesion policy (McCann, Ortega-Argilés, 
2015). This paper is more application-oriented, therefore we focused on a condensed theoretical background; a wider theoretical assessment of the learning region concept can be found in the above-mentioned studies (or see, for example, also Asheim, 2001).

\section{Data and methodology}

The targets of the National Program for Learning Regions are mainly focused on the support of science and research, innovation, employment, sustainable development and economic performance. The selection of regional indicators was customized in accordance with these targets, which matched with fields of study within the learning region concept, with respect to data accessibility. Data about partnership, networking or knowledge/information channels are unavailable within official regional statistics at the Slovak NUTS 3 level and cannot be included in our study; for this reason, we assumed its impact indirectly within the economic, environmental, innovation and social performance of regions. Similarly, like Bolcárová and Kološta (2015) we do not include regional GDP among the monitored indicators during indices construction because of its potential control function - the growth of the values of the proposed LR indices should also be reflected in the overall economic performance of the region as the main objective of all national program activities. With reference to main targets, we logically assume the desirable direction of chosen regional indicators as presented in Table 1 (values of the indicators Appendix Table 2a, b). These regional data were obtained from the databases of the Statistical Office of the Slovak Republic and the Office of Industrial Property of the Slovak Republic OIP SR (the number of patent applications in NUTS 3 regions was calculated from the web register of the OIP SR - therefore this dataset can be considered for the original dataset). These official databases are used by regional policy makers. In order to capture the trend of indicators, we analyzed the data for the 2008-2014 periods, which captured the crisis and the post-crisis period using the average values for the given period; i.e., we assumed that the indicators used should not deteriorate during periods of reviving economic growth.

With respect to the large correlations between the average data of the indicators (see correlation matrix including the average data of the indicators in the appendix Table 1), we used the Principal Component Analysis (PCA). The core idea of PCA is to reduce the dimensionality of a data set, which includes a large number of inter-related variables while retaining as much as possible the variation present in the data set (Jolliffe, 2002, p. 10). This method has already been used in creating the partial indices for Global Creativity Index (Florida et al., 2011, p. 29), the KOF index of globalization constructed by Dreher (2006), or the sustainable development index (Bolcárová and Kološta, 2015). Another reason for the choice of method was the different significance of the individual indicators, where some have greater and some minor importance (Bolcárová, Kološta, 2015). If we want to achieve a successful comparison and subsequent order of the regions in the Slovak Republic, it is not correct to decide which indicator is the best discriminatory factor, but it is instead necessary to take into account all indicators as a complex. This method is one of the most well-known methods of multidimensional analysis (Jolliffe, 2002). "The goal of the method is to transform the input multidimensional data, so that we get the data of the most important linear directions at the output, whereas the least significant directions are 
being ignored. From the original data, we extract the typical directions and simultaneously we reduce the data dimension." (Král' et al., 2009, p. 88). For the calculations, we used the SPSS statistical program, version 19.

\section{Table 1: Description of used regional indicators}

\begin{tabular}{|c|l|l|}
\hline $\begin{array}{l}\text { Premise routing } \\
\text { components } \\
\text { weighing PCA }\end{array}$ & Type of indicator & Indicator \\
\hline+ & R\&D, education, innovation & $\begin{array}{l}\text { Number of university graduates per } \\
\text { capita in region } \\
\text { R \& D expenditure per inhabitant in } \\
\text { region in } € \\
\text { Number of patent applications per } \\
\text { capita in region }\end{array}$ \\
+ & Social-economic & $\begin{array}{l}\text { Net migration per capita in region in } \% \\
\text { Unemployment rate in region in } \%\end{array}$ \\
+ & & $\begin{array}{l}\text { Regional gross added value per capita } \\
\text { in region in current prices }\end{array}$ \\
\hline+ & & $\begin{array}{l}\text { Amount of municipal waste per capita } \\
\text { in region in tons } \\
\text { Emission of basic pollutants per capita } \\
\text { in region in tons }\end{array}$ \\
\hline- & Environmental &
\end{tabular}

Source: Own processing

Values of the indicators were expressed in different units of measure; it was therefore necessary to standardize the values in order to achieve the elimination of unit influence (Král' et al., 2009). We calculated standard scores as follows (Stankovičová, Vojtková, 2007, p. 50):

$$
z_{i j}=\frac{x_{i j}-\bar{x}_{j}}{s_{x j}}
$$

where $z_{i j}$ is the standardized form of the indicator, $x_{i j}$ is the original value of the indicator, $\bar{x}_{j}$ is the arithmetic mean of the indicator, $s_{x j}$ is the standard deviation of the indicator. After the standardization of input data, we applied PCA using a covariance matrix (Král et al., 2009). Principal components can be expressed using the following formula (Král et al., 2009, p. 90):

$$
Z_{i}=v_{i}^{t} X
$$

where $Z_{i}$ is the $i$-th principal component, $v_{i}^{t}$ is the eigen vector corresponding to the eigenvalue $\lambda_{i}, X$ is input data of the standardized indicator values. 
With respect to interpretation, it is important to express the percentage of the variability captured by the first $m$ components in the total variability (Jolliffe, 2002, p. 113):

$$
t_{m}=100 \sum_{k=1}^{m} l_{k} / \sum_{k=1}^{p} l_{k}
$$

where $t_{m}$ is the percentage of variability captured by the first $m$ components, $l_{k}$ is the variability of the $k$-th component, $p$ is the number of input variables.

We usually extract principal components maintaining a prescribed percentage of the original variable's variability. As a selection criterion, it is also possible to use the Kaiser rule, which says that it is necessary to keep only those components with an eigenvalue greater than 1. By applying the PCA, we reduced the original number of variables within the 9 indicators to two principal components maintaining more than $90 \%$ of original variables' variability. The first principal component explains approximately $76 \%$ of the variability of the original 9 indicators. The second principal component represents approximately $16 \%$ of the variability. More detailed data about the variability explained by principal components are listed in Table 2. In our case, the first two principal components also met the Keiser rule.

Table 2: Overall explanation of variability

\begin{tabular}{|c|l|c|c|}
\hline Component & Total & \% of Variance & Cumulative \% \\
\hline 1 & 6,804 & 75,601 & 75,601 \\
\hline 2 & 1,48 & 16,448 & 92,049 \\
\hline 3 & 0,536 & 5,958 & 98,007 \\
\hline 4 & 0,152 & 1,691 & 99,699 \\
\hline 5 & 0,02 & 0,227 & 99,925 \\
\hline 6 & 0,006 & 0,07 & 99,996 \\
\hline 7 & 0 & 0,004 & 100 \\
\hline 8 & 0 & 0 & 100 \\
\hline 9 & 0 & 0 & 100 \\
\hline
\end{tabular}

Source: Own processing

The non-normalized coefficients of principal components were transformed into the standard ones listed in Table 3. According to Table 3, we assume that the indicators loaded highly in the first component lead to better economic and innovation conditions in the region, hence we called it an economic-innovative component (first partial LR index). This principal component is positively affected by increasing the share of $R \& D$ personnel on the total number of employed, the number of university graduates per capita, R\&D expenditure per capita, the number of patent applications per inhabitant, the migration per capita migration and the regional gross added value per capita in the region. 
Table 3: Component loadings

\begin{tabular}{|l|rr|}
\hline Indicator & 1. PC & 2. PC \\
\hline Share of R\&D employees out of total number of employees in region & 0,358 & $-0,263$ \\
Number of university graduates per capita in region & 0,370 & $-0,133$ \\
R\&D expenditure per inhabitant in region in € & 0,369 & $-0,198$ \\
Number of patent applications per capita in region & 0,342 & $-0,338$ \\
Net migration per capita in region in \% & 0,373 & 0,107 \\
Unemployment rate in region in \% & $-0,304$ & $-0,348$ \\
Regional gross added value per capita in region in current prices & 0,382 & $-0,040$ \\
Amount of municipal waste per capita in region in tons & 0,303 & 0,425 \\
Emission of basic pollutants per capita in region in tons & $-0,109$ & $-0,667$ \\
\hline
\end{tabular}

Source: Own processing

We called the second principal component the social-environmental component because it emphasizes the environmental and social spheres of the region to a greater extent (second partial LR index). Its value increases when the unemployment rate and emissions per capita are decreasing, and when the amount of municipal waste per capita in the region is increasing. Other indicators affected principal components to a lesser extent. In the first principal component, all regional indicators have the predicted weighing direction. Within the second principal component, the predicted direction does not indicate the amount of municipal waste per capita, but the resulting partial social-environmental index has predictive power. This discrepancy in comparison with the assumption is not so surprising, for example, due to low municipal waste recycling or weak waste management (Pomberger, Sarc, Lorber, 2017).

From the component scores of partial LR indices extracted using (3), we derived partial rankings of the regions separately for each LR partial index and based on the descending ordering of index values. In the next step, we assigned scores to regions based on the values of their partial LR indices as follows. We assigned the value equal to the number of objects in the component $(n)$ to a region with the highest score of an individual partial index, the value $(n-1)$ to the second-best region etc. Subsequently, we computed the aggregated LR index as a weighted average of the assigned scores utilizing the following formula (Stankovičová, Vojtková, 2007, p. 18):

$$
d_{1 i}=\sum_{j=1}^{k} s_{i j} \times v_{j}
$$

for $i=1,2, \ldots, n$, where $d_{1 i}$ is an integral indicator of the $i$-th region (aggregated index), $s_{i j}$ is the assigned score of the $i$-th region in the $j$-th LR partial index and $v_{j}$ is the weight of $j$-th LR partial index derived from the variability captured by the $j$-th principal component (\% of the variability attributable to the $j$-th principal component). Since only the first two principal components were included into construction of the aggregated LR index, we rescaled the weights so that the sum of these weights equals one. The aggregated 
LR index we then used to rank the regions in Slovakia, where ranking was extracted from descending ordering of index values. Our results are listed in Table 4.

\section{Results and discussion}

The resulting overall ranking of NUTS 3 regions in Slovakia allows the assessment of these regions for the period 2008-2014, for which the National Program for Learning Regions was developed. A high positive index score means tendency towards the main objectives of this programme (Table 4).

Table 4: Indices values and regional rankings

\begin{tabular}{|l|cccccc|}
\hline Region & $\begin{array}{c}\text { Eco-inov } \\
\text { index }\end{array}$ & $\begin{array}{c}\text { Eco-inov } \\
\text { ranking }\end{array}$ & $\begin{array}{c}\text { Soc-Enviro } \\
\text { index }\end{array}$ & $\begin{array}{c}\text { Soc-Enviro } \\
\text { ranking }\end{array}$ & $\begin{array}{c}\text { Overall LR } \\
\text { index }\end{array}$ & $\begin{array}{c}\text { Overall } \\
\text { ranking }\end{array}$ \\
\hline Bratislava & 6,147 & 1 & $-0,595$ & 7 & 6,775 & 2 \\
Trnava & 0,471 & 2 & 1,831 & 1 & 7,204 & 1 \\
Trenčín & $-0,647$ & 5 & $-0,075$ & 5 & 4,000 & 5 \\
Nitra & $-0,441$ & 3 & 1,169 & 2 & 6,204 & 3 \\
Žilina & $-0,521$ & 4 & 0,359 & 3 & 5,204 & 4 \\
Banská Bystrica & $-1,659$ & 7 & $-0,588$ & 6 & 2,204 & 7 \\
Prešov & $-2,14$ & 8 & 0,061 & 4 & 1,817 & 8 \\
Košice & $-1,187$ & 6 & $-2,192$ & 8 & 2,592 & 6 \\
\hline
\end{tabular}

Source: Own processing

Within the first economic-innovation partial LR index, only the Bratislava and Trnava regions achieved positive values. The highest value was achieved in the Bratislava ${ }^{6}$ region with a significantly higher value than other regions. Compared to the second-placed Trnava region, Bratislava's first index value was more than 13 times higher. The results showed that some regions achieved a similar value in the first LR index; a similar value was achieved by Nitra, Žilina and Trenčín region. Another group of regions was created from the Banská Bystrica and Košice regions. These results showed large economic-innovative disparities between Slovak regions, with strong dominance on the part of the Bratislava region.

In the second environmental and social partial LR index, the four regions reached positive values - Trnava, Nitra, Žilina and Prešov (regions with a low share of heavy industrial polluters). Negative index values were achieved by the Trenčín, Banská Bystrica, Bratislava and Košice regions; in this group there were regions with dominant steel and metallurgical industries - the Košice and Banská Bystrica regions; or there were regions with agglomerations with high population density and economic activities, which was the case for the Bratislava and Trenčín regions.

In calculating the aggregated LR index, the percentage of variability attributable to each of the principal component (Table 2) has to be taken into account. The highest value of the

\footnotetext{
${ }^{6}$ Within OECD regions, Bratislava is one of the top-ranked metropolitan regions in terms of growth of GDP and productivity per capita (OECD, 2013); the Bratislava region covers similar R\&D resources as the remaining Slovak NUTS 3 regions.
} 
aggregated LR index was achieved by the Trnava region. The second in terms of ranking was the Bratislava region, with a value lower by $6 \%$. These regions were followed by the Nitra, Žilina, Trenčín, Košice, Banská Bystrica and Prešov regions. The results showed relatively large differences between regions, and the regions of Trnava and Bratislava can be considered to be regions closest to the fulfillment of the main objectives of the National Program for Learning Regions. The differences between regions have emerged as a result of natural and social evolution (Viturka, 2010). However, too large differences are not perceived positively and can be a source of social tension (Klímová, Žítek, 2015), which can be especially noticeable in Košice, Prešov and the southern parts of the Banská Bystrica region.

Figure 1: Projection of regions according to first and second partial LR index

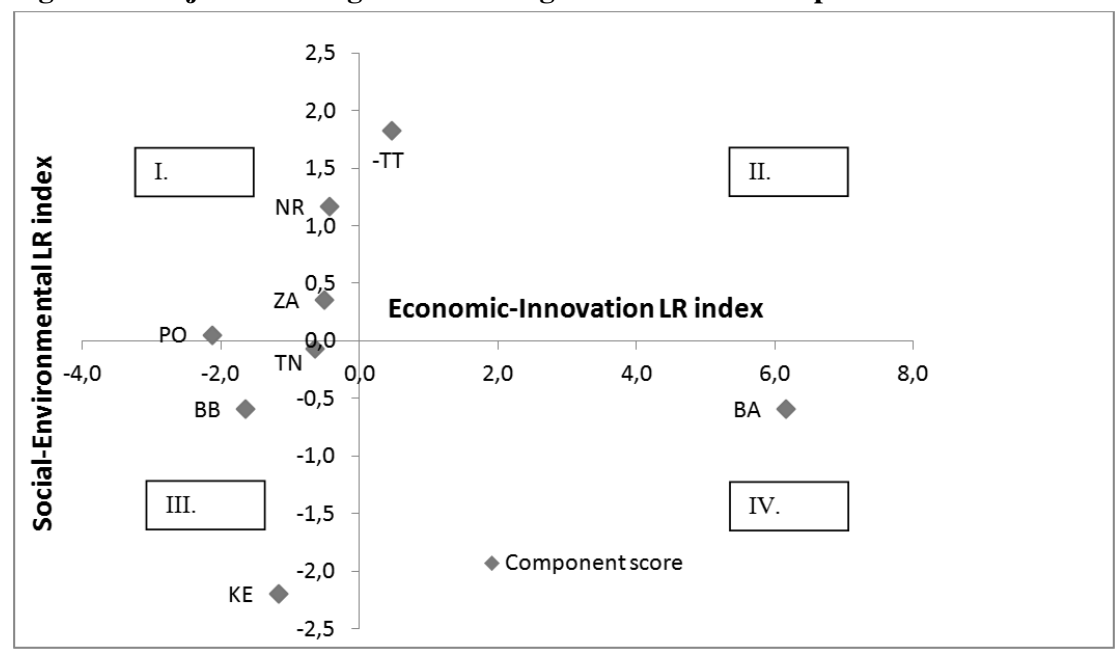

Source: Own processing

The first quadrant of Figure 1 represents regions where the values of the first economicinnovation partial LR index were negative; on the contrary, values in the second socialenvironmental partial LR index were positive. In this quadrant were placed the Nitra, Žilina and Prešov regions. These regions are lacking in economic and innovation dynamics, as evidenced by their negative values achieved under the first component (Table 4), which could have resulted in lower emissions caused by the absence of heavy industries, and therefore these regions have achieved positive values within the second social-environmental partial LR index. In these regions, regional policy should have focused more effectively on actions supporting economic and innovation dynamics to maintain environmental balance. The second quadrant of Figure 1 represents the desirable location of regions which achieved positive values in both components/indices. In this quadrant only the Trnava region was located from all Slovak NUTS 3 regions. This region can be considered efficient in terms of both economy and innovation, while at the same time achieving low emissions and unemployment rates. 
The third quadrant of Figure 1 shows the negative values of both components, and these regions show reduced economic and innovation as well as environmental and social dynamics. Each part of the Western, Central and Eastern part of Slovakia had such a region - regional policy in Trenčín (almost neutral within the second index), Banská Bystrica and Košice region does not seems to be supportive for economic/innovation/environmental and social performance and these regions are most obviously failing to reach the objectives of the national program.

The fourth quadrant of Figure 1 includes regions that reached positive values for the first component and negative values for the second component. This quadrant included only the Bratislava region, which is a highly economically successful and innovative region, but this positive feature seems to be at the expense of environmental indicators. Regional policy should be focused on the support and use of green technologies.

Regional GDP was excluded from LR indices construction due to its potential as a control variable. Using the values of aggregated LR index in relation to the average GDP per capita in Slovak NUTS 3 regions in the years 2008-2014, we reached a moderate correlation ( $R=0.618)$, respectively; there exists strong correlation $(R=0.882)$ if we exclude the Bratislava region due to its clearly economic dominance. The first economic and innovation partial LR index was in accordance with our assumption - its very strong correlation with the average GDP per capita $(R=0.997)$. The second social-environmental partial LR index with average GDP per capita did not correlate substantially at all $(R=-0.05)$. These results were influenced by the strength of the individual components, which were dominated by the first principal component explaining more than $75 \%$ of the variability of the original variables.

As the learning region concept is emphasized not only in the economic but also in the social and environmental spheres, it would be desirable in future to achieve progress towards positive values in both partial LR indices within Slovak NUTS 3 regions. Future perspectives and changes in economic structure of regions will be crucial for sustainability of Slovak regions and economic and innovative conditions seem to have the highest relevance influencing overall regional environment.

\section{Conclusion}

The main motivation for the construction of an aggregated index evaluating economicinnovation and socio-environmental indicators was to streamline the presentation and monitoring of partial progress in achieving the objectives of the National Program for Learning Regions in the Slovak Republic for policy-makers, and to make this relatively complex issue accessible through the one aggregated and two partial indices to the wider audience as to what proposed indices were fulfilled. The proposed methodology for the construction of aggregated indices by PCA can be used by the Ministry of Education, Science, Research and Sport as well as by regional policy-makers in the Slovak Republic within decision-making processes resulting in achieving the objectives of the National Program for Learning Regions - improving living conditions and sustainable economic performance. Furthermore, the proposed index can be linked to various indicators, as we showed using GDP per capita. The presented and used PCA methodology can be 
adopted, tested and developed also in other geographical areas, as an assessment tool within learning region or other regional concepts or strategies which are dealing with a large number of inter-related variables, to provide relevant information about overall progress towards defined targets for national and regional policy-makers.

The highest value of aggregated LR index was reached by the Trnava region, followed by the Bratislava region. The results showed relatively large differences between the regions. The Trnava and Bratislava regions came closest to reaching the objectives of the National Program for Learning Regions (these regions reached the highest positive values of both partial LR indices). The lowest values were found in the Banská Bystrica, Prešov and Košice regions. For these less developed regions, the activities of the Australian region Gwydir may be inspirational, through which new ways of learning in cooperation with entrepreneurs and local communities have actually improved the living conditions of declining areas, ultimately contributing to the mitigation of the acquired knowledge incompatibility with the needs of the labor market, greatly reducing the migration of young people, and making more effective use of the potential of the territory (see Mitchell, 2006). Our indices used regional macro-data, which could not reflect various qualitative changes influencing living conditions of inhabitants and this field can be studied in more depth in future.

The learning region concept is concerned with respecting the principle of equal attention to social, economic and environmental development (Matthiesen, Reutter, 2003). Therefore, not only the economic benefit of the region but also social and environmental development should be followed. The ideal balance in the economic, social and environmental spheres is very difficult to achieve in the economic practice of the countries because of the different understanding of economic policy and different historical and economic development (Tvrdoň, 2008). The range of indicators that can now be statistically collected at the Slovak NUTS 3 level and which allowed us to evaluate Slovak regions in terms of the main objectives of the National Program for Learning Regions therefore cannot be considered definitive. For other relevant indicators at the NUTS 3 level, we would recommend collecting data such as the average age of healthy years of survival of the population in the region, number of collaborating enterprises/networking, value and variants of use of ecosystem services, stress assessment, population satisfaction with life in the region, water/air/soil quality, type of agriculture in \% (bio/intensive), security, improving lifelong learning monitoring, environmental degradation, resilience to climate change, or assessing income polarization in the regions. This would be a combination of quantitative and qualitative indicators, which would provide a more comprehensive view on a more complex assessment of the National Program for Learning Regions in Slovakia and could stimulate broader professional discussion, otherwise lacking, about suitable indicators and assessment tools. Therefore, a more comprehensive evaluation of the National Program for Learning Regions in Slovakia will need to monitor and collect data for previously unregistered regional characteristics in order to make the most comprehensive assessment possible. 


\section{Acknowledgements}

We would like to thank our editor Helena Campbelle and two anonymous reviewers for helpful comments.

\section{References}

Asheim, B. T. (2001). Learning Regions as Development Coalitions: Partnership as Governance in European Workfare States? Concepts and Transformation. International Journal of Action Research and Organizational Renewal, 6, 73-101.

Asheim, B., Grillitsch, M., Trippl, M. (2015). Regional Innovation Systems: Past - Presence - Future. Papers in Innovation Studies, Paper no. 2015/36.

Bathelt, H. and Gluckler, J. (2003). Towards a 'relational economic' geography. Journal of Economic Geography, 3, 117-144.

Bathelt H., Malmberg A. and Maskell, P. (2004). Clusters and knowledge: local buzz, global pipelines and the process of knowledge creation. Progress in Human Geography, 28, 31-56.

Boekema, F. et al. (2001). Knowledge, innovation and economic growth: the theory and practice of learning regions. Cheltenham: Edward Elgar.

Boggs, J. S. and Rantisi, N. M. (2003). The relational turn in economic geography. Journal of Economic Geography, 3, 109-116.

Bolcárová, P. and Kološta, S. (2015). Assessment of sustainable development in the EU 27 using aggregated SD index. Ecological Indicators, 48, 699-705.

Dreher, A. (2006). Does globalization affect growth? Evidence from a new index of globalization. Applied Economics, 38, 1091-1110.

Faulconbridge, J. R. (2006). Stretching tacit knowledge beyond a local fix? Global spaces of learning in advertising professional service firms. Journal of Economic Geography, 6, 517-540.

Faulconbridge, J. R. (2007). London's and New York's Advertising and Law Clusters and their Networks of Learning: Relational Analyses with a Politics of Scale? Urban Studies, 44, 1635-1656.

Florida, R. (1995). Toward the learning region. Futures, 27(5), 527-536.

Florida, R., Mellander, Ch., Stolarick, K. (2011). Creativity and Prosperity: The Global Creativity Index. Martin Prosperity Institute, Toronto.

Gustavsen, B., Nyhan, B., Ennals, R. (2007). Learning together for local innovation: promoting learning regions. Luxembourg: Office for Official Publications of the European Communities.

Hassink, R., Klaerding, C. (2012). The End of the Learning Region as We Knew It; Towards Learning in Space. Regional Studies, 46(8), 1055-1066.

Hudson, R. (1999). The learning economy, the learning firms and the learning regions: a sympathetic critique of the limits to learning. European Urban and Regional Studies, $6(1), 59-72$.

Jolliffe, I. T. 2002. Principal Component Analysis. Second Edition. Springer - Verlag New York, Inc. 
Klímová, V., Žítek, V. (2015). Inovační paradox v Česku: ekonomická teorie a politická realita. Politická ekonomie, 63(2), 147-166.

Kološta, S. (2016). Učiaci sa región - východiská, podstata, kritika, využitie. Belianum EF UMB.

Král, P. et al. (2009). Viacrozmerné štatistické metódy so zameraním na riešenie problémov ekonomickej praxe. Banská Bystrica: Ekonomická fakulta UMB.

Lorenzen, M. (1998). Localised learning; Why are inter-firm learning patterns institutionalised within particular localities? Copenhagen Business School Working Paper. IVS/CBS Working Papers 98-10.

Lorenzen, M. (2001). Localized Learning and Policy: Academic Advice on Enhancing Regional Competitiveness through Learning. European Planning Studies, 9, 163-185.

Lorenzen, M. (2007). Social Capital and Localised Learning: Proximity and Place in Technological and Institutional Dynamics. Urban Studies, 44, 799-817.

Lundvall, B. A. (1992). National systems of innovation: towards a theory of innovation and interactive learning. London: Pinter.

Malmberg, A. and Maskell, P. (2006). Localized Learning Revisited. Growth and Change, $37,1-18$.

Matthiesen, U., Reutter, G. (2003). Lehrende region - Mythos oder Lebendige Praxis? Deutsches Institut für Erwachsenenbildung.

McCann, P., Ortega-Argilés, R. (2013). Smart Specialization, Regional Growth and Applications to European Union Cohesion Policy. Regional Studies, 49, 1291-1302.

Mitchell, J. G. (2006). The Gwydir Learning Region Model: An independent evaluation. Sydney.

Morgan, K., (1997). The learning region: institutions, innovation and regional renewal. Regional Studies, 31, 491-503.

Newlands, D. (2003). The role do universities in learning regions. 43rd Congress of the European Regional Science Association.

OECD. (2001). Cities and Regions in the New Learning Economy. Paris.

OECD. (2013). OECD Regions at a Glance 2013. OECD Publishing.

Pomberger, R., Sarc, R., Lorber, K. E. (2017). Dynamic visualisation of municipal waste management performance in the EU using Ternary Diagram method. Waste management, 61, 558-571.

Preisinger-Kleine, R. (2013). An Analytical Quality Framework for Learning Cities and Regions. International Review of Education, 59(4), 521-538.

Ronde, P., Hussler, C. (2003). The role of competences on patenting activities of learning regions: an empirical study on French data. 43rd Congress of the European Regional Science Association.

Rutten, R. and Boekema, F. (2007). A future for the learning region. In RUTTEN R. and BOEKEMA, F. (Eds.). The Learning Region: Foundations, State of the Art, Future, 275-292. Edward Elgar, Cheltenham.

Saxena, G. (2005). Relationships, networks and the learning regions: case evidence from the Peak District National Park. Tourism Management, 26, 277-289. 
Schamp, E. W. (2009). Coevolution von Wissen und Raum? - Ein kritischer Bericht aus der Wirtschaftsgeographie. Disp, 177, 70-78.

Šipikal, M. (2013). Tailoring Innovation Policies to Sectors and Regions - The Case of Slovakia. Danube: Law, Economics and Social Issues Review, 4, 277-291.

Šipikal, M., Parízková, J. (2009). Učiace sa regióny. EKONÓM: Ekonomická univerzita v Bratislave.

Stankovičová, I., Vojtková, M. (2007). Viacrozmerné štatistické metódy s aplikáciami. Iura Edition.

Storper, M. (1997). The Regional World: Territorial Development in a Global Economy. Guilford Press, New York and London.

Strambach, S. (1998). Knowledge-intensive business services (KIBS) as an element of learning regions - the case of Baden-Württemberg. 38th Congress of the European Regional Science Association.

Tvrdoň, M. (2008). Institucionální aspekty fungování trhu práce. Politická ekonomie, 56(5), 623-642.

Viturka, M. (2010). Nový př́stup $k$ hodnocení disparit v regionálním rozvoji. Klímová (ed.) XIII. mezinárodní kolokvium o regionálních vědách.

Yeung, H. W-C. (2005). Rethinking relational economic geography. Transactions of the Institute of British Geographers, 30, 37-51. 


\section{Appendix}

Table 1: Correlation matrix from average indicators 2008-2014 Pearson correlation coefficient

\begin{tabular}{|c|c|c|c|c|c|c|c|c|c|c|}
\hline \multirow{4}{*}{\begin{tabular}{|l|} 
PracVav \\
\end{tabular}} & & PracVav & $\overline{A b s V S}$ & VydVav & PatPrih & MigSaldo & MieraNezam & RegH PH & Odpady & Emisie \\
\hline & $\begin{array}{l}\text { Pearson } \\
\text { Correlation }\end{array}$ & 1 & ,985 & ,987 & ,959 & ,877 &,- 557 & ,953 & ,555 &,- 080 \\
\hline & Sig. (2-tailed) & & ,000 & ,000 & ,000 &, 004 &, 152 & ,000 &, 154 &, 850 \\
\hline & $\mathrm{N}$ & 8 & 8 & 8 & 8 & 8 & 8 & 8 & 8 & 8 \\
\hline \multirow[t]{3}{*}{ AbsVS } & $\begin{array}{l}\text { Pearson } \\
\text { Correlation }\end{array}$ & ,985 & 1 & ,972 & ,907 & ,932 &,- 618 & ,973 & ,662 &,- 209 \\
\hline & Sig. (2-tailed) & ,000 & & ,000 & ,002 & ,001 & , 102 & ,000 & ,074 & ,620 \\
\hline & $\mathrm{N}$ & 8 & 8 & 8 & 8 & 8 & 8 & 8 & 8 & 8 \\
\hline \multirow[t]{3}{*}{ VydVaV } & $\begin{array}{l}\text { Pearson } \\
\text { Correlation }\end{array}$ & ,987 & ,972 & 1 & ,973 & ,893 &,- 638 & ,974 & ,600 &,- 137 \\
\hline & Sig. (2-tailed) &, 000 & ,000 & & ,000 &, 003 & ,089 & ,000 &, 116 & ,747 \\
\hline & $\mathrm{N}$ & 8 & 8 & 8 & 8 & 8 & 8 & 8 & 8 & 8 \\
\hline \multirow[t]{3}{*}{ PatPrih } & $\begin{array}{l}\text { Pearson } \\
\text { Correlation }\end{array}$ & ,959 & ,907 & ,973 & 1 & ,789 &,- 567 & ,910 & ,466 & ,056 \\
\hline & Sig. (2-tailed) & ,000 & ,002 & ,000 & & ,020 & ,142 & ,002 & ,244 & ,896 \\
\hline & $\mathrm{N}$ & 8 & 8 & 8 & 8 & 8 & 8 & 8 & 8 & 8 \\
\hline \multirow[t]{3}{*}{ MigSaldo } & $\begin{array}{l}\text { Pearson } \\
\text { Correlation }\end{array}$ & ,877 & ,932 & ,893 & ,789 & 1 &,- 793 & ,969 & ,857 &,- 371 \\
\hline & Sig. (2-tailed) & ,004 & ,001 & ,003 &, 020 & & ,019 & ,000 & ,007 & ,365 \\
\hline & $\mathrm{N}$ & 8 & 8 & 8 & 8 & 8 & 8 & 8 & 8 & 8 \\
\hline \multirow[t]{3}{*}{$\begin{array}{l}\text { Miera- } \\
\text { Nezam }\end{array}$} & $\begin{array}{l}\text { Pearson } \\
\text { Correlation }\end{array}$ &,- 557 &,- 618 &,- 638 &,- 567 &,- 793 & 1 &,- 755 &,- 926 & ,397 \\
\hline & Sig. (2-tailed) & ,152 & ,102 & ,089 &, 142 & ,019 & & ,030 & ,001 & ,331 \\
\hline & $\mathrm{N}$ & 8 & 8 & 8 & 8 & 8 & 8 & 8 & 8 & 8 \\
\hline \multirow[t]{3}{*}{ RegHPH } & $\begin{array}{l}\text { Pearson } \\
\text { Correlation }\end{array}$ & ,953 & ,973 & ,974 & ,910 & ,969 &,- 755 & 1 & ,757 &,- 262 \\
\hline & Sig. (2-tailed) &, 000 & ,000 & ,000 & ,002 & ,000 & ,030 & & ,030 & ,531 \\
\hline & $\mathrm{N}$ & 8 & 8 & 8 & 8 & 8 & 8 & 8 & 8 & 8 \\
\hline \multirow[t]{3}{*}{ Odpady } & $\begin{array}{l}\text { Pearson } \\
\text { Correlation } \\
\end{array}$ & ,555 & ,662 & ,600 & ,466 & ,857 &,- 926 & ,757 & 1 &,- 488 \\
\hline & Sig. (2-tailed) &, 154 &, 074 &, 116 & ,244 & ,007 & ,001 & ,030 & & ,220 \\
\hline & $\mathrm{N}$ & 8 & 8 & 8 & 8 & 8 & 8 & 8 & 8 & 8 \\
\hline \multirow[t]{3}{*}{ Emisie } & $\begin{array}{l}\text { Pearson } \\
\text { Correlation }\end{array}$ &,- 080 &,- 209 &,- 137 &, 056 &,- 371 & 397 &,- 262 &,- 488 & 1 \\
\hline & Sig. (2-tailed) & 850 &, 620 & ,747 & ,896 & ,365 & ,331 & ,531 & ,220 & \\
\hline & $\mathrm{N}$ & 8 & 8 & 8 & 8 & 8 & 8 & 8 & 8 & 8 \\
\hline
\end{tabular}

Source: Own processing 
Table 2a: Average values of indicators of Slovak NUTS 3 regions 2008-2014

\begin{tabular}{|l|c|l|c|l|c|}
\hline Region & $\begin{array}{l}\text { Share of R\&D } \\
\text { employees out } \\
\text { of total } \\
\text { number of } \\
\text { employees in } \\
\text { region }\end{array}$ & $\begin{array}{l}\text { Number of } \\
\text { university } \\
\text { graduates } \\
\text { per capita in } \\
\text { region }\end{array}$ & $\begin{array}{l}\text { R\&D } \\
\text { expenditure } \\
\text { per inhabitant } \\
\text { in region in } €\end{array}$ & $\begin{array}{l}\text { Number of } \\
\text { patent } \\
\text { applications } \\
\text { per capita in } \\
\text { region }\end{array}$ & $\begin{array}{l}\text { Net migration } \\
\text { per capita in } \\
\text { region in \% }\end{array}$ \\
\hline Bratislava & 0,041 & 0,039 & 401,983 & $9,09 \mathrm{E}-05$ & 0,720 \\
Trnava & 0,006 & 0,011 & 50,087 & $2,07 \mathrm{E}-05$ & 0,280 \\
Trenčín & 0,005 & 0,006 & 67,295 & $3,69 \mathrm{E}-05$ & $-0,060$ \\
Nitra & 0,007 & 0,012 & 35,737 & $1,88 \mathrm{E}-05$ & 0,050 \\
Žilina & 0,008 & 0,009 & 65,011 & $3,35 \mathrm{E}-05$ & $-0,020$ \\
Banská Bystrica & 0,007 & 0,009 & 38,355 & $2,35 \mathrm{E}-05$ & $-0,090$ \\
Prešov & 0,003 & 0,005 & 18,352 & $2,14 \mathrm{E}-05$ & $-0,150$ \\
Košice & 0,012 & 0,011 & 69,680 & $3,95 \mathrm{E}-05$ & $-0,060$ \\
\hline
\end{tabular}

Source: Own processing using data from Statistical Office of the Slovak Republic and the Office of Industrial Property of the Slovak Republic

Table 2b: Average values of indicators of Slovak NUTS 3 regions 2008-2014

\begin{tabular}{|l|c|c|c|c|}
\hline Region & $\begin{array}{l}\text { Unemployment } \\
\text { rate in region } \\
\text { in \% }\end{array}$ & $\begin{array}{l}\text { Regional gross } \\
\text { added value per } \\
\text { capita in region } \\
\text { in current prices }\end{array}$ & $\begin{array}{l}\text { Amount of } \\
\text { municipal waste } \\
\text { per capita in } \\
\text { region in tons }\end{array}$ & $\begin{array}{l}\text { Emission of basic } \\
\text { pollutants per } \\
\text { capita in region } \\
\text { in tons }\end{array}$ \\
\hline Bratislava & 4,956 & 28584,224 & 0,439 & 0,025 \\
Trnava & 8,047 & 13116,100 & 0,422 & 0,012 \\
Trenčín & 9,390 & 10447,437 & 0,336 & 0,094 \\
Nitra & 11,710 & 10193,360 & 0,374 & 0,018 \\
Žilina & 10,867 & 10214,654 & 0,316 & 0,038 \\
Banská Bystrica & 18,346 & 8566,170 & 0,270 & 0,066 \\
Prešov & 17,901 & 6925,543 & 0,247 & 0,020 \\
Košice & 17,010 & 9316,399 & 0,267 & 0,168 \\
\hline
\end{tabular}

Source: Own processing using data from Statistical Office of the Slovak Republic and the Office of Industrial Property of the Slovak Republic 